\title{
Indoor radon levels in Hungarian kindergartens
}

\author{
Anita Csordás ${ }^{1} \cdot$ Katalin Zsuzsanna Szabó ${ }^{2} \cdot$ Zoltán Sas $^{3} \cdot$ Erika Kocsis $^{1} \cdot$ Tibor Kovács $^{1} \mathbb{C}$
}

Received: 8 October 2020 / Accepted: 6 November 2020 / Published online: 6 January 2021

(c) The Author(s) 2021

\begin{abstract}
Annual average indoor radon activity concentration was studied in 88 Hungarian kindergartens in 76 towns of 10 different counties. Annual average indoor radon activity concentration in the kindergartens was $61 \mathrm{~Bq} \mathrm{~m}^{-3}$, maximum was $160 \mathrm{~Bq}$ $\mathrm{m}^{-3}$. In the kindergartens the seasonal variation of radon is not so strong like in dwellings, because of the permanent ventilation and the closed period during the summer break.
\end{abstract}

Keywords Indoor radon concentration · Kindergartens · Radon survey, CR-39

\section{Introduction}

The main part of the natural background radiation is from the radon ( $\mathrm{Rn}-222)$ isotope, which is a colorless, odorless and chemically inert noble gas. It is the one gas in the U-238 decay series. In closed places-like homes or workplaces-it can accumulate and mainly through its daugter isotopes (e.g. Po-214, Po-218) can increase the lung cancer risk which was evidenced by the epidemiological studies [1-5]. The World Health Organization (WHO) identified the radon as the second leading cause of the lung cancer after the smoking [6].

In order to reduce the lung cancer risk several international organizations published recommendation about the acceptable indoor radon concentration. In the actual recommendation of the European Union (which is the same as the International Atomic Energy Agency's recommendation) the reference level of indoor radon concentration is $300 \mathrm{~Bq}$ $\mathrm{m}^{-3}$ [7].

The new EU directive obligate the member countries to prepare and continuously review a Radon Action Plan, which includes the country's medium- and long-term actions

Tibor Kovács

kt@almos.uni-pannon.hu

1 Department of Radiochemistry and Radioecology, University of Pannonia, Veszprém, Hungary

2 Nuclear Security Department, Centre for Energy Research, Budapest, Hungary

3 Social Organisation for Radioecological Cleanliness, Veszprém, Hungary to reduce the lung cancer risk of the radon exposure. Therefore, the monitoring and controlling of indoor radon concentration are emphasized in dwelling and workplaces, respectively. In this regard, the kindergartens are special: they are workplaces and living place at the same time [8].

Zhukovsky et al. [9] made a literature review of indoor radon measurements in kindergartens and schools in 63 countries, of which 42 are European, but Hungary is not among them. The detectors used for the surveys were diverse, LR-115, charcoal, Radhome Si Det, Makrofol, Electret, Lucas cell, but mostly CR-39. The average population weighted arithmetic mean of radon was $59 \mathrm{~Bq} \mathrm{~m}^{-3}$, geometric mean was $36 \mathrm{~Bq} \mathrm{~m}^{-3}$ and the geometric standard deviation was 2.7 in these 63 countries [9]. They found that the estimated number of objects with radon concentration higher than $300 \mathrm{~Bq} \mathrm{~m}^{-3}$ in children's institutions is about $1.5 \%$ that is 5 times higher than in the dwellings.

Studies in foreign countries showed that some percentage, $3-10 \%$ of the studied kindergartens have higher indoor radon concentration than the reference level applied in the country [10-16].

One of the largest studies was conducted in Norway, where radon concentration in 3660 , out of totally approx. 6500 kindergartens in the country, was measured using etched track detectors. However, only in the heating season for two months. They found that $9.2 \%$ of the kindergartens were above $200 \mathrm{~Bq} \mathrm{~m}^{-3}[10]$.

Bem et al. [11] found maximum $139 \mathrm{~Bq} \mathrm{~m}^{-3}$ in the winter season in 106 Polish kindergartens based on measurements. They used Plastic Pico-Rad detectors with activated charcoal, which were exposed for $48 \mathrm{~h}$ during winter. 
Ďurčík et al. [12] assessed radon risk in 388 kindergartens and 257 basic schools by long-term (12 months or 6 months containing winter) indoor radon measurements in Slovakia. They used LR-115 and CR-39 detectors. The arithmetic and geometric mean of EER (equilibrium equivalent radon) were $57.5 \mathrm{~Bq} \mathrm{~m}^{-3}$ and $34.5 \mathrm{~Bq} \mathrm{~m}^{-3}$ in the kindergartens, respectively. They found higher than $200 \mathrm{~Bq} \mathrm{~m}^{-3}$ (their action level) in 13 kindergartens [12].

Vaupotic et al. [13, 14] performed systematic measurements of indoor radon concentrations and gamma dose rates in 730 kindergartens and play schools in Slovenia. They used alpha scintillation cells, but in cases with an increased instantaneous radon concentration, the additional methods of track-etch detectors and alpha spectroscopy were applied. Only 50 kindergartens have radon concentration higher than $200 \mathrm{~Bq} \mathrm{~m}^{-3}$. However, in 16 kindergartens it was between 800 and $5600 \mathrm{~Bq} \mathrm{~m}^{-3}[13,14]$ Vaupotic et al. [15] remediated two kindergartens where the average heating season indoor radon concentration was about $2000 \mathrm{~Bq} \mathrm{~m}^{-3}$. Radon concentration was reduced successfully by $80 \%$ [15].

Ivanova et al. [16] measured indoor radon concentration by CR-39 in 296 kindergartens in Bulgaria but only for 3 months from February to April. They found 6\% of the studied kindergartens with higher than $300 \mathrm{~Bq} \mathrm{~m}^{-3}$ indoor radon concentrations in the studied period. Arithmetic mean was $132 \mathrm{~Bq} \mathrm{~m}^{-3}$, maximum was $1415 \mathrm{~Bq} \mathrm{~m}^{-3}$ [16].

Several studies in Hungary dealt with radon measurements and dose assessment in indoor places like residential homes, public places (hospital, libraries, temples, schools and kindergartens), workplaces, caves, mines, wine cellars. But only a few measurements were performed in kindergartens and the kindergarten data were not published separately from other indoor data $[17,18]$. However, it is well known that children are one of the most sensitive to all kinds of harm, including ionizing radiation. Thus knowledge about the harmful radon in kindergartens, selfevident aim of us all.

In this study we examined 88 kindergartens in 76 towns in the middle and western part of the country (Fig. 1) to check if there is any of them which has radon concentration above the reference level, $300 \mathrm{~Bq} \mathrm{~m}^{-3}$ in Hungary (487/2015. (XII. 30.) Govt. Degree). Another aim of the project was to study that is there any correlation between indoor radon concentration and different parameters of the kindergarten such as building type, windows type (ventilation frequency), year of construction, type of the rooms and presence of cellar, insulation, and slag built-in.

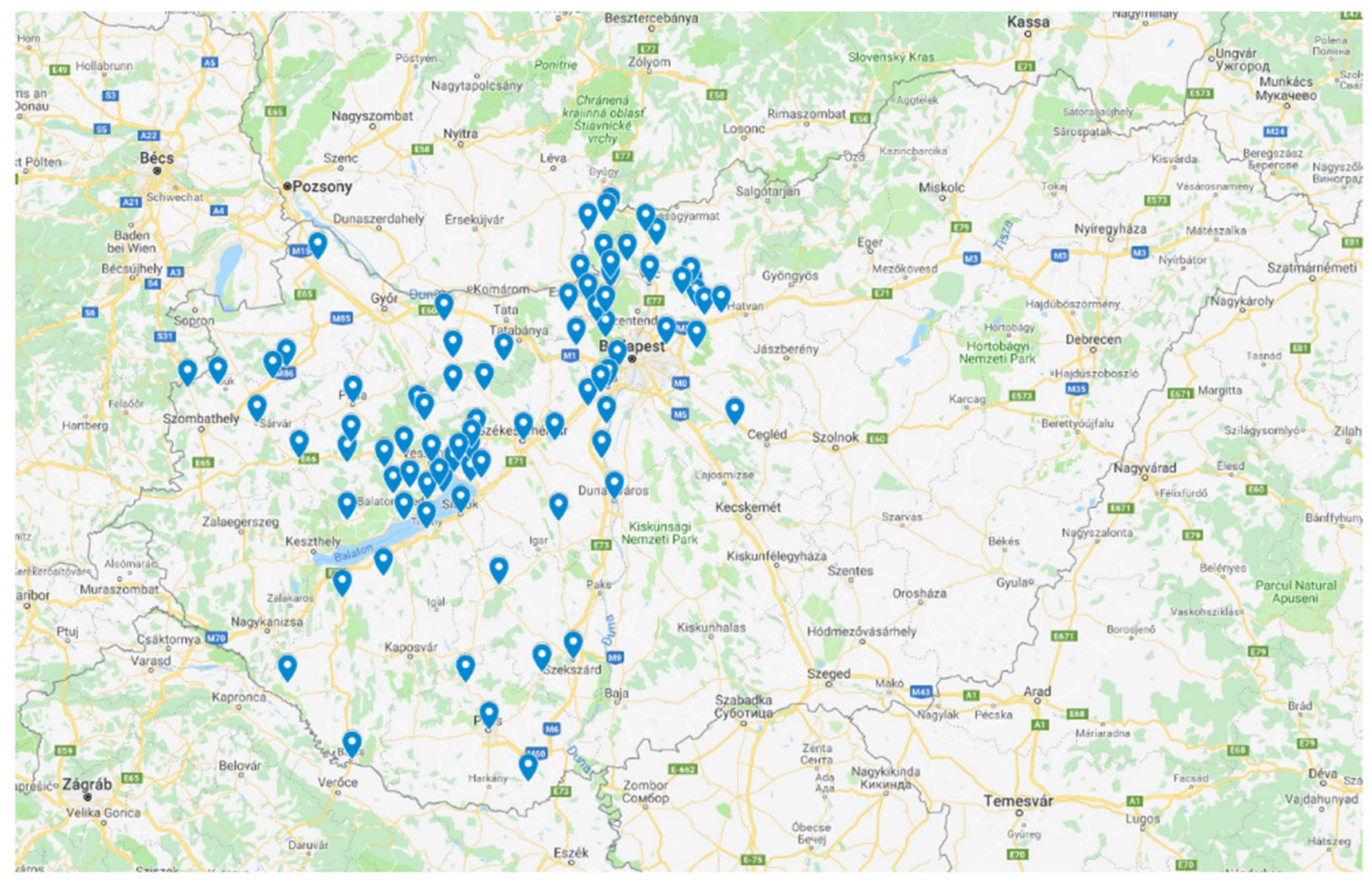

Fig. 1 Location of the studied kindergartens 


\section{Material and methods}

\section{Site description}

Selection of the studied kindergartens based on the previous indoor radon [18, 19] and geogenic radon potential [20] surveys. The kindergartens closest to the locations, where the highest soil gas radon activity concentration or geogenic radon potential or indoor radon concentration in dwellings was determined, were selected.

At the beginning of the survey every major of the cities/ towns/villages on the selected areas was contacted via e-mail and they were informed about the survey. The participation was voluntary.

\section{Study design}

In this study the indoor radon measurement was carried out in 195 rooms of 88 kindergartens, which were in 10 different counties out of the 19 counties of the country (Table 1). The most measured kindergartens were in Veszprém and Pest counties (30 and 24\%, respectively) and the least were in Baranya, Győr-Moson-Sopron and Nógrád counties (2\%, 2-2 kindergartens in each). Basically, indoor radon concentration was measured in 3 rooms in order to characterize the kindergarten as accurately as possible. However, we also had considered the size of the building, so we measured in one $(36 \%)$, two $(8 \%)$, three $(53 \%)$ or four $(2 \%)$ rooms. Because the main part of the indoor radon is from the soil in the most cases, and the conventionally accepted method to measure the indoor radon concentration is measuring on the ground floor, we performed the measurements basically on the ground floor $(96 \%)$. In some cases, we also performed measurements in the basement (1\%), where for example the gym was placed, or in the first floor (3\%) (Table 1). In some kindergartens located in the hilly areas we performed measurements on different floors because of the rising ground level (Table 1).

In the 88 kindergartens the measurement was performed in 195 rooms with different function (group room, office, kitchen, dressing room, gym) (Table 2). The most measurements were in group rooms (173), where children stay most, the least was in dressing rooms and kitchens (4-4) (Table 2). The remaining 14 rooms were 7 offices and 7 gyms.

\section{Building characteristics}

At the beginning of the radon survey a questionnaire was filled with the contacts of every kindergarten. This form contains the most important building's parameters, which are presented in the Table 3.

Most of the studied kindergartens were built between 1946 and 1989 and only 3 before 1900 . The most commonly used building material is the brick (67\%) the remaining $33 \%$ used rubble, concrete, adobe, aerated concrete, lightweight construction or wood. More than half of the kindergartens do not have cellar (59\%) and $26 \%$ of them has partly. About half of the kindergartens do not have external insulation the other half do (Table 3 ). In $78.5 \%$ of the kindergartens have well-closed windows, which means usually new types of plastic windows and $20.5 \%$ have draughty windows (oldtype wood windows).

\section{Indoor radon measurement}

Radon activity concentration was measured by CR-39 track detectors in each season for one year, Autumn: SeptemberNovember, Winter: December-February, Spring: MarchMay, Summer: June-August. The predefined measurement
Table 1 Number of the studied kindergartens and rooms in the different administrative divisions (counties) and the building levels where the detectors were placed

\begin{tabular}{|c|c|c|c|c|c|c|c|c|}
\hline \multirow[t]{2}{*}{ County } & \multirow[t]{2}{*}{$\begin{array}{l}\text { Number of the kin- } \\
\text { dergartens }(\mathrm{N} / \%)\end{array}$} & \multicolumn{4}{|c|}{$\begin{array}{l}\text { Number of the } \\
\text { measured rooms } \\
\text { (N) }\end{array}$} & \multicolumn{3}{|c|}{ Level where the detector is placed $(\mathrm{N})$} \\
\hline & & 1 & 2 & 3 & 4 & Basement & Ground floor & First floor \\
\hline Baranya & $2(2)$ & 2 & 0 & 0 & 0 & 0 & 2 & 0 \\
\hline Fejér & $10(11)$ & 5 & 1 & 4 & 0 & 1 & 18 & 0 \\
\hline Győr-Moson-Sopron & $2(2)$ & 2 & 0 & 0 & 0 & 0 & 2 & 0 \\
\hline Komárom-Esztergom & $12(14)$ & 7 & 1 & 4 & 0 & 1 & 20 & 0 \\
\hline Nógrád & $2(2)$ & 0 & 0 & 2 & 0 & 0 & 6 & 0 \\
\hline Pest & $21(24)$ & 0 & 1 & 19 & 1 & 0 & 60 & 3 \\
\hline Somogy & $5(6)$ & 5 & 0 & 0 & 0 & 0 & 5 & 0 \\
\hline Tolna & $3(3)$ & 3 & 0 & 0 & 0 & 0 & 3 & 0 \\
\hline Vas & $5(6)$ & 5 & 0 & 0 & 0 & 0 & 5 & 0 \\
\hline Veszprém & $26(30)$ & 3 & 4 & 18 & 1 & 0 & 67 & 2 \\
\hline Total & $88(100)$ & 32 & 7 & 47 & 2 & 2 & 188 & 5 \\
\hline
\end{tabular}


Table 2 Number and type of the measured rooms in each county

Table 3 Building characteristics of the studied kindergartens

\begin{tabular}{llcllll}
\hline Country & $\begin{array}{l}\text { Number of } \\
\text { rooms (N/\%) }\end{array}$ & \multicolumn{2}{l}{ Type of the room $(\mathrm{N})$} & & \\
\cline { 3 - 7 } & & Group room & Office & Kitchen & $\begin{array}{l}\text { Dressing } \\
\text { room }\end{array}$ & Gym \\
\hline Baranya & $2(1)$ & 2 & 0 & 0 & 0 & 0 \\
Fejér & $19(9.7)$ & 17 & 2 & 0 & 0 & 0 \\
Győr-Moson-Sopron & $2(1)$ & 2 & 0 & 0 & 0 & 0 \\
Komárom-Esztergom & $21(10.8)$ & 18 & 1 & 1 & 0 & 1 \\
Nógrád & $6(3.1)$ & 3 & 0 & 2 & 0 & 1 \\
Pest & $63(32.3)$ & 55 & 2 & 1 & 3 & 2 \\
Somogy & $5(2.6)$ & 5 & 0 & 0 & 0 & 0 \\
Tolna & $3(1.5)$ & 3 & 0 & 0 & 0 & 0 \\
Vas & $5(2.6)$ & 4 & 0 & 0 & 0 & 1 \\
Veszprém & $69(35.4)$ & 64 & 2 & 0 & 1 & 2 \\
Total & 195 & 173 & 7 & 4 & 4 & 7 \\
\hline
\end{tabular}

\begin{tabular}{|c|c|c|c|}
\hline $\begin{array}{l}\text { Parameters of building char- } \\
\text { acteristics }\end{array}$ & Categories & $\begin{array}{l}\text { Number of kindergar- } \\
\text { tens }(\mathrm{N} / \%)\end{array}$ & $\begin{array}{l}\text { Number of } \\
\text { rooms }(\mathrm{N} / \%)\end{array}$ \\
\hline \multirow[t]{5}{*}{ Year of construction } & Before 1900 & $3(3)$ & $7(4)$ \\
\hline & $1900-1945$ & $9(10)$ & $26(13)$ \\
\hline & $1946-1989$ & $54(61)$ & $125(64)$ \\
\hline & After 1990 & $11(13)$ & $23(12)$ \\
\hline & Not known & $11(13)$ & $14(7)$ \\
\hline \multirow[t]{10}{*}{ Building material } & Brick & $59(67)$ & $123(63)$ \\
\hline & Rubble & $7(8)$ & $21(11)$ \\
\hline & Concrete & $7(8)$ & $18(9)$ \\
\hline & Adobe & $3(3.4)$ & $9(5)$ \\
\hline & Brick + rubble & $3(3.4)$ & $8(4)$ \\
\hline & Aerated concrete & $3(3.4)$ & $4(2)$ \\
\hline & Lightweight construction & $2(2.3)$ & $6(3)$ \\
\hline & Brick + concrete + rubble & $2(2.3)$ & $2(1)$ \\
\hline & Wood & $1(1.1)$ & $3(1.5)$ \\
\hline & Not known & $1(1.1)$ & $1(0.5)$ \\
\hline \multirow[t]{4}{*}{ Presence of cellar } & Has cellar & $12(14)$ & $29(14.9)$ \\
\hline & Partly has cellar & $23(26)$ & $55(28.4)$ \\
\hline & Has no cellar & $52(59)$ & $110(56.7)$ \\
\hline & Not known & $1(1)$ & $1(0.5)$ \\
\hline \multirow[t]{4}{*}{ External insulation } & Has insulation & $41(47)$ & $85(44)$ \\
\hline & Partly has insulation & $1(1)$ & $3(1.5)$ \\
\hline & Has no insulation & $45(51)$ & $106(54)$ \\
\hline & Not known & $1(1)$ & $1(0.5)$ \\
\hline \multirow[t]{3}{*}{ Windows type } & Draughty & $18(20.5)$ & $36(18.5)$ \\
\hline & Well-closed & $69(78.5)$ & $158(81)$ \\
\hline & Not known & $1(1)$ & $1(0.5)$ \\
\hline
\end{tabular}

period was one year from September 2015 to September 2016, however, in many cases, the measurements shifted due to the late re-posting of the detectors. This caused changes in the predefined measurement periods. First placement of detectors were basically done personally-except for in case of remote locations, to where the detectors were sent by post-, when the questionnaire was also completed. Replacement of detectors between the seasons was always done by post. Detectors were placed on a shelf about $1.5-2 \mathrm{~m}$ height and $15-20 \mathrm{~cm}$ from the wall. 
After the radon exposure the detectors were chemically etched in sodium-hydroxide solution $\left(8 \mathrm{~h}, 90{ }^{\circ} \mathrm{C}, 6.25 \mathrm{M}\right)$. After the chemical treatment, the detectors were cleaned with distilled water and alcohol. The determination of the track densities (tracks $\mathrm{mm}^{-2}$ ) was carried out by the "IDES" scanner-based evaluation system, which was developed at the Institute of Radiochemistry and Radioecology [21].

The own background of the CR-39 detector was 0.5 tracks $\mathrm{mm}^{-2}$. The minimum measurable radon activity concentration was influenced by the type of the diffusion chamber. During this survey the NRPB type was selected. The minimum measurable radon activity concentration is $20.6 \mathrm{~Bq}$ $\mathrm{m}^{-3}$ for this type with 3-month exposure time, the value of LLD is $44.5 \mathrm{kBq} \mathrm{h} \mathrm{m}^{-3}$. The sensitivity of CR-39 detectors (Baryotrak type) was between 1.5 and 1.7 depending on the storage time before the measurement. The calibration process and the determination of the calibration factor was carried out in the own calibration chamber with a certified radon source.

\section{Results and discussion}

\section{Raw indoor radon activity concentration data (each room, each season, individually)}

First column of the Table 4 shows the summary statistics of the raw data (each room, each season, individually). The arithmetic mean of indoor radon activity concentration is $60 \mathrm{~Bq} \mathrm{~m}^{-3}$, geometric mean is $50 \mathrm{~Bq} \mathrm{~m}^{-3}$, the maximum value was $288 \mathrm{~Bq} \mathrm{~m}^{-3}$, which was an autumn-winter measurement on the ground floor, where the building material is rubble, the windows are well-closed, there is slag built-in and there is no cellar and insulation. Figure 2 shows the histrogram, quantile plot, box-whisker plot and the scatter plot of the raw indoor radon activity concentration data (each room, each season, individually). Raw data has lognormal distribution $(p=0.17)$ according to the KolmogorovSmirnov Test (Fig. 2).

Figure 3 shows the seasonal variation of the raw indoor radon activity concentration data. It has an expected pattern, lowest in summer and highest in autumn, winter and spring. Seasonal variation of radon in kindergartens is less than in residential homes [18, 22, 23]. In Hungary the mechanical ventilation is not typical, such as e.g. in Norway [24], but the windows are open all day, even in winter, in tilt position. This can be the reason of the small seasonal variation.

\section{Annual average indoor radon activity concentration in the studied 195 rooms of the 88 kindergartens}

Second column of the Table 4 shows the summary statistics of the annual average radon concentration in the 195

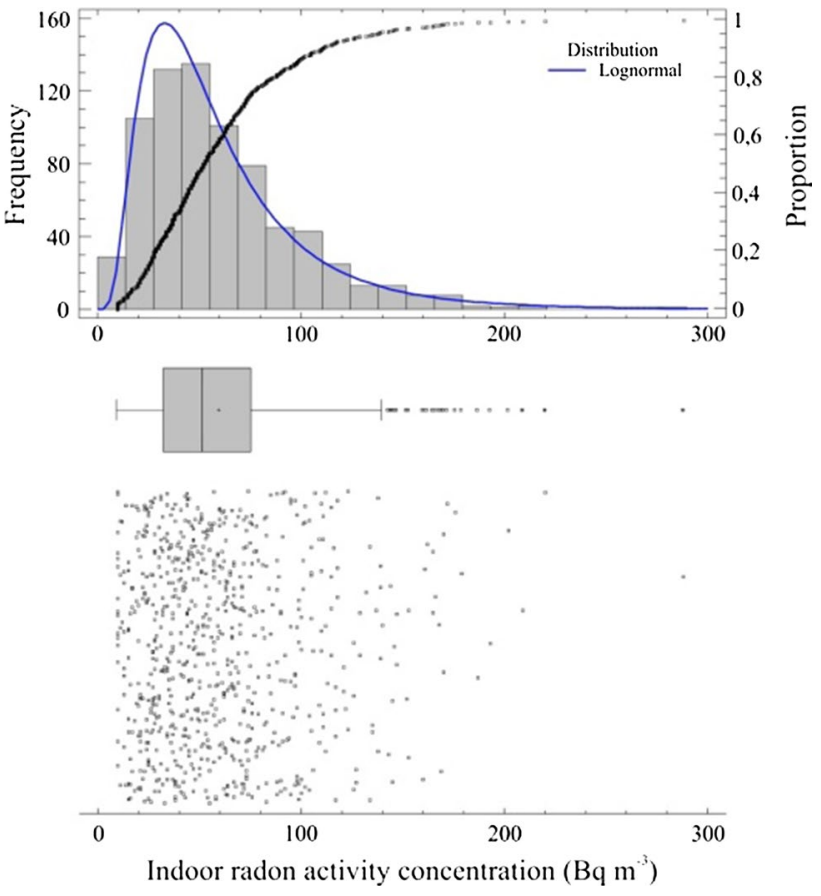

Fig. 2 Histogram, quantile plot, box-whisker plot and scatter plot of the raw indoor radon activity concentration data (each room, each season, individually). Blue line is the density function of the fitted lognormal distribution

rooms of the 88 studied kindergartens. The arithmetic mean of indoor radon activity concentration is $60 \mathrm{~Bq} \mathrm{~m}^{-3}$, geometric mean is $52 \mathrm{~Bq} \mathrm{~m}^{-3}$, and the maximum value is 160 $\mathrm{Bq} \mathrm{m}^{-3}$. Third column of the Table 4 shows the summary statistics of the annual average radon concentration in 88 studied kindergartens. The arithmetic mean of indoor radon activity concentration is $61 \mathrm{~Bq} \mathrm{~m}^{-3}$, geometric mean is 54 $\mathrm{Bqm}^{-3}$, and the maximum value is $160 \mathrm{~Bq} \mathrm{~m}^{-3}$. These average values are similar the measurement results found in 63 other countries introduced by Zhukovsky et al. [9].

Highest annual average radon concentration was find in the offices $\left(74 \mathrm{~Bq} \mathrm{~m}^{-3}\right)$ and the lowest one in the gyms $\left(46 \mathrm{~Bq} \mathrm{~m}^{-3}\right)$, however, there is no statistically significant difference between the radon concentrations of different types of rooms according to the Kruskal-Wallis Test (Fig. 4). Note that the highest annual average indoor radon concentration values (high outliers) were found in the group rooms (155 and $160 \mathrm{~Bq} \mathrm{~m}^{-3}$ ) (Fig. 4a).

We checked if there is any difference between in the radon concentration of the kindergartens regarding the year kindergarten was built (Fig. 4b). We selected four groups of the years. First group is kindergartens built before 1900, before the economic and social development bringing our country similar to Western countries. Second is 1900-1945, years of the two world wars. Third is 1946-1989 after the Second World War until the regime change in Hungary. It 
Table 4 Summary statistics of the indoor radon activity concentration data

\begin{tabular}{lcc}
$\begin{array}{l}\text { Raw indoor radon data (each room, each } \\
\text { season, individually) }\left(\mathrm{Bq} \mathrm{m}^{-3}\right)\end{array}$ & $\begin{array}{l}\text { Annual average indoor radon data in the } \\
\text { different rooms }\left(\mathrm{Bq} \mathrm{m}^{-3}\right)\end{array}$ & $\begin{array}{l}\text { Annual average indoor radon } \\
\text { data in the kindergartens } \\
\left.\mathrm{m}^{-3}\right)\end{array}$ \\
\hline 742 & 195 & 88 \\
10 & 14 & 16 \\
33 & 36 & 39 \\
50 & 52 & 54 \\
52 & 52 & 56 \\
60 & 60 & 61 \\
76 & 78 & 78 \\
288 & 160 & 160 \\
37 & 31 & 29
\end{tabular}

$L Q$ lower quartile, $G M$ geometric mean, $U Q$ upper quartile, $S D$ standard deviation

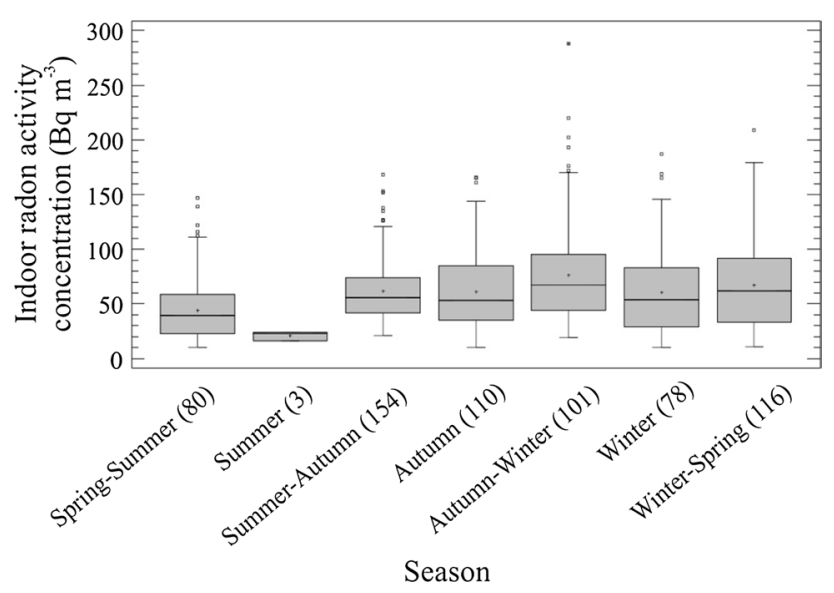

Fig. 3 Box-whisker plot of the raw indoor radon activity concentration data in the different seasons. Numbers in the brackets on the $\mathrm{X}$ axis are the number of measurements

is well known that during these years slag and fly ashes from heavy industry were built in the houses and any type of buildings as filling material in the ceiling or the floor countrywide in Hungary. The fourth group is the kindergartens constructed after 1990. Lowest concentrations were found in kindergartens built after 1990. Highest values were found in kindergartens built between 1946 and 1989 (155 and $160 \mathrm{~Bq}$ $\mathrm{m}^{-3}$, average is $63 \mathrm{~Bq} \mathrm{~m}^{-3}$ ). Among these kindergartens 24 have no slag built-in, 4 have slag built-in and in case of 33 kindergartens it is not known if there is slag built-in or not. Based on the measured radon results, it is conceivable that where there is no information about the built-in slag there is slag just they do not know about it.

As it was expected annual average indoor radon concentration is higher in those rooms where the windows are well-closed (new windows) $\left(45 \mathrm{~Bq} \mathrm{~m}^{-3}\right)$ than in rooms with draughty (old) windows $\left(64 \mathrm{~Bq} \mathrm{~m}^{-3}\right)$ (Fig. 4c).
Those rooms where slag is built-in have the highest annual average radon concentration $\left(72 \mathrm{~Bq} \mathrm{~m}^{-3}\right)$ than rooms without it $\left(55 \mathrm{~Bq} \mathrm{~m}^{-3}\right)$. Rooms with no information on built-in slag have higher annual average indoor radon concentration $\left(63 \mathrm{~Bq} \mathrm{~m}^{-3}\right)$ than those without slag and lower than rooms with built-in slag (Fig. 4d). This result also supports the above mentioned assumption that where there is no information about the built-in slag there is slag just they do not know about it.

In kindergartens where there is a cellar underneath, the annual average indoor radon concentration on the ground floor is lower $\left(56 \mathrm{~Bq} \mathrm{~m}^{-3}\right)$ than in those where there is partially or no cellar at all (both are $63 \mathrm{~Bq} \mathrm{~m}^{-3}$ ) (Fig. 4e). However, they are not significantly different according to the Kruskal-Wallis Test.

Kindergartens with insulation show a little bit higher values $\left(66 \mathrm{~Bq} \mathrm{~m}^{-3}\right)$ than without insulation $\left(56 \mathrm{~Bq} \mathrm{~m}^{-3}\right)$ but not a significantly different annual average indoor radon concentration values according to the Kruskal-Wallis Test (Fig. 4F).

Regarding the building material, radon activity concentration is less in wood, concrete (26 and $33 \mathrm{~Bq} \mathrm{~m}^{-3}$, respectively) and higher in brick, rubble and adobe construction (62, 70 and $77 \mathrm{~Bq} \mathrm{~m}^{-3}$, respectively) (Fig. 5).

\section{Conclusion}

None of the studied 88 kindergartens in the 76 towns had higher than $300 \mathrm{~Bq} \mathrm{~m}^{-3}$ annual average radon activity concentration (Hungarian reference level), even in individual seasons. Arithmetic and geometric mean of indoor radon concentration of this survey is similar to find in 63 other countries. The seasonal variation of indoor radon in the studied kindergartens was not so strong, like usually in the dwellings, because of the continuous ventilation and the closed period in summer in the kindergartens. Highest 

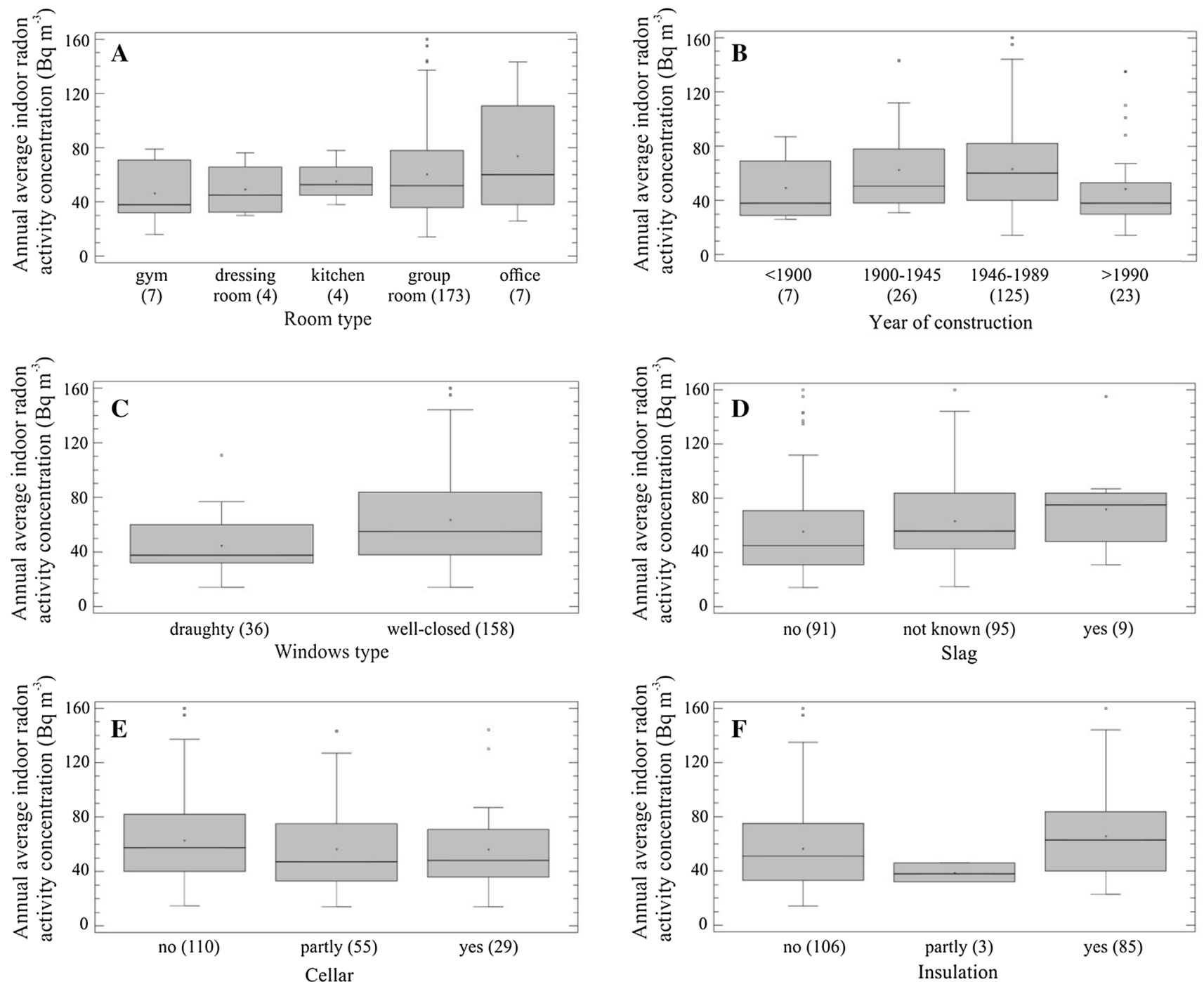

Fig. 4 Multiple sample comparison of annual average indoor radon activity concentration and the kindergarten parameters. a Type of rooms. b Year of construction. c Windows type (ventilation fre-

quency). d Slag built-in. e Presence of cellar. f Presence of insulation. Numbers in the brackets on the $\mathrm{X}$ axis are the number of measurements

values were found in kindergartens built between 1946 and 1989 (155 and $\left.160 \mathrm{~Bq} \mathrm{~m}^{-3}\right)$. It is well known that during these years slag and fly ashes from heavy industry were used as filling material in the ceiling or the floor in buildings countrywide in Hungary. This is also supported by the fact that in the kindergartens where slag is found we got higher values $\left(72 \mathrm{~Bq} \mathrm{~m}^{-3}\right)$ than in those where slag is not built-in $\left(55 \mathrm{~Bq} \mathrm{~m}^{-3}\right)$. Well-closed windows caused higher indoor radon concentration $\left(64 \mathrm{~Bq} \mathrm{~m}^{-3}\right)$

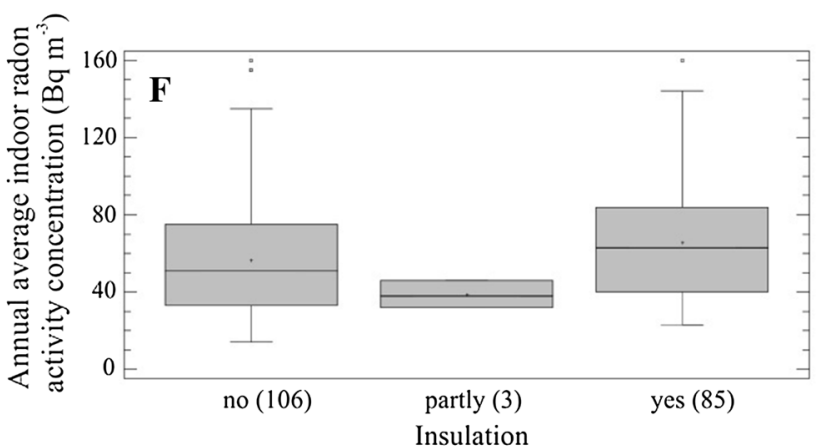

than draughty ones $\left(45 \mathrm{~Bq} \mathrm{~m}^{-3}\right)$. Regarding the building material, annual average radon activity concentration is less in wood, concrete ( 26 and $33 \mathrm{~Bq} \mathrm{~m}^{-3}$, respectively) and higher in brick, rubble and adobe construction $(62,70$ and $77 \mathrm{~Bq} \mathrm{~m}^{-3}$, respectively). Comparing the results from this survey with data from other European survey (which was introduced in this paper), the arithmetic and geometric mean was similar in each survey. 


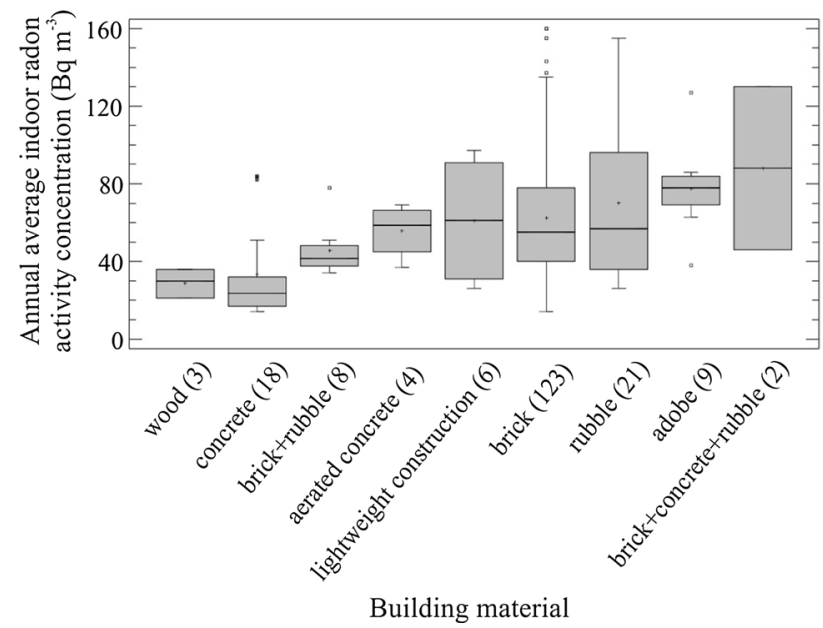

Fig. 5 Box-whisker plot of the annual average indoor radon activity concentration regarding the different building materials (in the order of the average). Numbers in the brackets on the $\mathrm{X}$ axis are the number of measurements

Acknowledgements The research work is supported by the Hungarian National Research OTKA grant No. K128805 and K128818.

Funding Open access funding provided by University of Pannonia.

Open Access This article is licensed under a Creative Commons Attribution 4.0 International License, which permits use, sharing, adaptation, distribution and reproduction in any medium or format, as long as you give appropriate credit to the original author(s) and the source, provide a link to the Creative Commons licence, and indicate if changes were made. The images or other third party material in this article are included in the article's Creative Commons licence, unless indicated otherwise in a credit line to the material. If material is not included in the article's Creative Commons licence and your intended use is not permitted by statutory regulation or exceeds the permitted use, you will need to obtain permission directly from the copyright holder. To view a copy of this licence, visit http://creativecommons.org/licenses/by/4.0/.

\section{References}

1. National Research Council (US) (1999) Committee on Health Risks of Exposure to Radon (BEIR VI). National Academies, Press (US) Washington, DC, USA ISBN 0-309-05645-4

2. Tubiana M, Aurengo A, Averbeck D, Masse R (2006) Recent reports on the effect of low doses of ionizing radiation and its dose-effect relationship. Radiat Environ Biophys 44:245-251

3. Scott BR (2011) Residential radon appears to prevent lung cancer. Dose Response 9(4):444-464

4. Duan P et al (2015) Nonlinear dose-response relationship between radon exposure and the risk of lung cancer: evidence from a metaanalysis of published observational studies. Eur J Cancer Prev 24:267-277

5. Field RW et al (2001) The Iowa radon lung cancer study-phase I: residential radon gas exposure and lung cancer. Sci Total Environ 272(1-3):67-72
6. WHO (2009) WHO Handbook on Indoor Radon-A Public Health Perspective. Geneva Switzerland, p 110

7. Council Directive 2013/59/Euratom (2013) Euratom Basic Safety Standards BSS. Off. J. Eur. Union, p 73

8. Vaupotic J (2011) Radon in kindergartens and schools: a review. In: Li Z, Feng C (eds) Handbook of Radon. Hauppauge, NY, USA

9. Zhukovsky M, Vasilyev A, Onishchenko A, Yarmoshenko I (2018) Review of indoor radon concentrations in schools and kindergartens. Radiat Prot Dosim 181:6-10

10. BirovljevA, Strand T, Heiberg A (1998) In: D P (ed) Radon concentration on Norwegian kindergartens. Proceedings of the 2. International Yugoslav Nuclear Society Conference. Antic (YUNSC'98). p 790.ISBN 86-7306-023-0; ISSN 1450-5525, 629-634

11. Bem H, Bem EM, Ostrowska M (1999) Radon concentrations in kindergartens and schools in the Łódź region of Poland. Radiat Prot Dosim 82:147-149

12. Durčík M, Havlík F, Vičanová M, Nikodemová D (1997) Radon risk assessment in Slovak kindergartens and basic schools. Radiat Prot Dosim 71:201-206

13. Vaupotič J,Križman M,Planinić J,Pezdič J,Adamič K,Stegnar $\mathrm{P}$,Kobal I (1994a) Systematic indoor radon and gamma measurements in kindergartens and play schools in Slovenia. Health Phys. 66:550-556

14. Vaupotič J, Bezek M, Kávási N, Ishikawa T, Yonehara H, Tokonami S (2012) Radon and thoron doses in kindergartens and elementary schools. Radiat Prot Dosim 152:247-252

15. Vaupotič J, Križman M, Planinić J, Kobal I (1994b) Radon level reduction in two kindergartens in Slovenia. Health Phys 66:568-572

16. Ivanova K, Stojanovska Z, Tsenova M, Badulin V, Kunovska B (2014) Measurement of indoor radon concentration in kindergartens in Sofia, Bulgaria. Radiat Prot Dosim 162:163-166

17. Hámori K, Tóth E, Pál L, Köteles G, Losonci A, Minda M (2006) Evaluation of indoor radon measurements in Hungary. J Environ Radioact 88:189-198

18. Múllerová M, Kozak K, Kovács T, Smetanová I, Csordás A, Grzadziel D, Holý K, Mazur J, Moravcsík A, Neznal M, Neznal M (2016) Indoor radon survey in Visegrad countries. Appl Radiat Isotopes 110:124-128

19. Szeiler G, Somlai J, Ishikawa T, Omori Y, Mishra R, Sapra B, K,Mayya YS, Tokonami S, Csordás A, Kovács T (2012) Preliminary results from an indoor radon thoron survey in Hungary. Radiat Prot Dosim 152:243-246

20. Szabó KZ, Jordan G, Horváth Á, Szabó C (2014) Mapping the geogenic radon potential: methodology and spatial analysis for central Hungary. J Environ Radioact 214:74-83

21. Csordás A, Bátor G, Horváth D, Somlai J, Kovács T (2016) Validation of the scanner based radon track detector evaluation system. Radiat Meas 87:1-7

22. Bossew P, Lettner H (2007) Investigations on indoor radon in Austria, Part 1: Seasonality of indoor radon concentration. J Environ Radioact 98:329-345

23. Szabó Zs J, Gy, Szabó C, Horváth Á, Holm Ó, Kocsy G, Csige I, Szabó P, Homoki Zs (2014) Radon and thoron levels, their spatial and seasonal variations in adobe dwellings - a case study at the great Hungarian plain. Isot Environ Health Stud 50(2):211-225

24. Norwegian Radiation Protection Authority (NRPA) Report (2015) Protocol for radon measurements in schools and kindergartens

Publisher's Note Springer Nature remains neutral with regard to jurisdictional claims in published maps and institutional affiliations. 